\title{
A Review on Conflicting Issues in a Deferred Payment Sale Product
}

\section{of a Shari'Ah-Compliant Banking Business}

\author{
Mohd Nasir bin Mohd Yatim \\ Department of Finance and Economic, College of Business and Accounting \\ UNITEN Muadzam Shah. Pahang. Malaysia \\ Tel: 60-9-455-2025Ｅ-mail: nasir@uniten.edu.my
}

\begin{abstract}
The objective of this study is to look into the proper practices in handling of a product of shari'ah-compliant banking, namely the deferred payment sale (al-bai' bithaman ajil). The elements of violation of shari'ah dictates in dealing with shari'ah-compliant banking practices were identified. This study contributed in term of understanding the issues that need to be improved as innovation at the banking institution level in the form of standard procedural instruction or policy. Exploratory approach to research method was extensively used in this study as such method is relevant for the research issues being studied. The evidences were derived from field work conducted on one type of investment product, al-bai' bithaman ajil of a bank. Capitalizing on the explored and examined shortcomings, improvement on the manner that such shari'ah-compliant banking instrument be handled in efficient and effective ways in order to compete in the intense local and global markets are recommended.
\end{abstract}

Keywords: Shari'ah, Al-bai’ bithaman ajil, Gharar, Riba, Ijab and qabul

\section{Introduction}

The integration of Islamic banking business within the operation of conventional banking activities into the global banking system will inevitably expose to new challenges in both compliance and legal systems. This is the result of the process of development and complexities involved in arriving at the innovation of Islamic banking products. Of course, our concern is on the arising implications due to an oversight on the substance over form and legal form aspects of the resulted innovation. Apart from this, justice, fairness and ethical practices in the dealings of Islamic banking business need to be addressed.

This paper discussed the issues in handling a product of deferred payment sale, a form of debt financing offered by a bank operating shari'ah-compliant banking business. Currently the premises for offering shari'ah-compliant instruments have already been made available both of mandatory and voluntary in nature. The issues being addressed in here are on the properness of the practices of the offered product so that it is equitable in kind. Such innovation shall reflect the conformance of its shari'ah-compliant and free from any form of ambiguity or gharar. Despite the impressive improvement in the performance of Islamic banking activities, there are still shortcomings emerged from the ill-equipped system to meet the challenges of customers' demand.

Gregory (1996) commented that in the era of a new revolution, knowledge and applied intelligence are rapidly becoming the keys to survival and success. The innovative and creative approaches in designing of a new branding product shall be viewed as a niche in strengthening the competitive edge of the modern banking. In this regard, it is worth suggesting that the shari'ah-compliant investment vehicles be handled equitably.

\section{Literature review}

The current academic and business interest in Islamic banking and finance is a product of a considerable amount of Islamic resurgence leading to movement for reform and return to basic shari'ah principles in many Islamic countries. Kamel Naser and Maurice Pendlebury (1997) as well as Abdul Magid (1986) demonstrated the appearance of Islamic movement led to the development in term of unified Islamic political and economic system that could have a significant impact on the pattern of international trade.

The legal form for an investment vehicle will involve considering the advantages and disadvantages of the business forms available. In ensuring the legitimacy of an Islamic banking product, its promoter must not only confine it adherence to the national law instead it has to be beyond this spectrum of legal environment. Thus, it also needs to observe on the compliance of shari'ah, national regulation, tax structure, accounting and auditing as well as market demand. Stewardship and accountability are important to ensure that investors' confidence is not eroded (Kamel Naser and Maurice Pendlebury, 1997). 
The focus of this study is looking into the issues related to the properness in the handling of a specific product using the concept of al-bai' bithaman ajil, a form of debt financing to facilitate the financing of a landed property. It is aimed at improving the manner in which the product is properly packaged and administered so as to benefit both the seller and buyer parties. Information concerning economic events nowadays is getting more complex. This gives rise to increasingly difficult to keep track of resources, to ascertain them and to ensure that they are used for the intended purposes. As such, effort in devising and administering the product must properly be observed. This is in agreement with the assertion that, accounting itself is a product of its environment taking into consideration the social, economic, political and legal conditions (Mohd Nasir, 1993).

Politically, the public has the right to know how the private sector operates in the public interest to maintain a good social image. This is to ensure public acceptance of its existence as part of the economic system (Barton, 1982). As such, in ensuring this properness of product in term of its pricing, placement and in this case its conformance to shari'ah-compliant requirement must be observed.

\section{Research Methodology}

This study emphasized on qualitative approach using analytical and comparative methods. The comparative method was conducted to establish the conformance and permissibility of the operational aspect to that of the shari'ah dictates. The terms and conditions and contents of applicable documents to an asset based on a deferred payment sale (al-bai bithaman ajil) concept were scrutinized with reasonable in-depth and broad perspective to justify the holistic nature of the issues focused. For the purpose of justifying the acceptable values in operating a shari'ah base banking business, the shari'ah values are defined as information which is relevant to the shari'ah business conducts and dealings.

Currently, development of shari'ah banking products and legal documentations are still following normative approach. This can be traced when looking and scrutinizing closely at the contents of the related documentations. This research uses documentations of a bank dealing with shari'ah way of banking business. It purposely looked into a case that dealt with deferred payment sale contract (al-bai bithaman ajil). Thus, this study focused primarily on related documents that are related to such contract.

It was hypothesized in this study that, the existing approaches in handling the shari'ah-compliant banking product of al-bai' bithaman ajil is not equitable to the customers. This hypothesis is thus related to the aspect and manner in which the bank handles the instrument. In evidencing the correctness of the assertion in the hypothesis, relevant documents and dealing records were studied and analyzed.

\section{Findings and Discussion}

Practically, a letter of offer is to substantiate the elements of offer and acceptance (sighah) as one of the tenets in a contract of buy and sell in a deferred payment sale contract. It is a part and parcel of the legal documentations for the specific contract's dealings. In this study, it is related to an asset of a bank utilizing the concept of al-bai bithaman ajil. The element of pricing in this contract has been reviewed analytically. The writer found that there was element of multiple pricing within a single contract of the deferred payment sale. This is a form of violation in the contract, leading to ambiguity (gharar). There was stipulation of grace period profit (GPP) pricing apart from the sale pricing quoted in there, within sale and purchase contract of a deferred payment sale. Further scrutinizing on the letter of offer, found that, the element of interest was mentioned. There was also presence of penalty interest clause in such document. Such clause appeared in the specific term and condition of the letter of offer which was quoted as follow:

"In the event of any late payment after its due date, in addition to interest or penalty interest that may be charged, the Bank is entitled to levy an administrative charge which the Bank may from time to time stipulate."

This was an evidence of violation to the shari'ah-compliant banking and finance principle of usury (al-riba). This was not in line as what used to be commented by other writers. The condemnation of usury is part of the general condemnation of market abuse, such as exploitation of weaker members of society by deceit, manipulation or restriction (Kamel Naser and Maurice Pendlebury, 1997). In discussing on the existence of physical nature of good or the subject matter of the contract, Islamic banking places it's reliance over the specification of which may not turn to be a real one at the point of delivery of the object or good. Timeliness in the process of preparation and execution of documentations was another issue that needs to be addressed in the case of this study. Inefficiency was glaring in this case, delay in the process may lead to unnecessary interest ( $r i b a$ ) be imposed by the developer and hence non-competitive. Inadequacy of competency level of practitioners contributed to such phenomenon.

Analytical scrutiny was conducted on the shari'ah-compliant mortgage insurance (mortgage takaful) coverage policy. The writer noted that there was element of speculation (maisr) in the document. There was a form of manipulation of information to the advantage of the operator. When looking into the application of mortgage insurance cover in this study, it was noted that it was jointly applied aimed at covering property of a common interest to both the joint-applicants. In other word it was earlier meant to cover both parties when making the proposal for such mortgage cover. However, when the policy was issued, it was only be available to protect for the possible economic losses of the 
first applicant only, who is much younger in age and not to benefit him for the possible economic losses of the second applicant, who is much older than him as the protection was not being granted. In this regard, it was seen that the takaful operator was taking advantage by gambling on the customer's life. The bank which acted as an agent of its subsidiary takaful business has clearly acted in the manner to benefit its takaful unit rather than its customer by providing single cover on the possible economic losses of the younger applicant in lieu of his death. This kind of protection is not benefiting the younger applicant in this joint proposal mortgage cover.

The bank should have acted with caution that nourishment or livelihood, life partner and death solely are in the hand of the Almighty. This was a serious offence, as it may be conflicting with the principle of aqidah for merely believing that the elderly person may pass away earlier, even though the rule of thumb base on logic may be right. In discussing this a little further, the bank absolutely cannot say that in twenty years from now, the elderly person may pass away earlier than the younger one. Thus, this was another clear evidence of violation of mu'amalah principles, in the day-to-day practices of shari'ah-compliant banking business. In this regard, justification on elements of fairness and morality have to be focused in holistic manner with reasonable in-depth. Of course, suggestion on the improvement of approach needs to be considered through formulating universally accepted practices.

Operationally, administering the financing is another crucial aspect of handling shari'ah-compliant banking practices. Numerous issues which were deemed to be the weaknesses in practices need to be addressed. These include the imposition of service charge on every repayments made under a standing instruction even both the financing account and deposit account were held in the same branch office of the bank. Such phenomenon may hinder the effectiveness as well as contributing to element of risk being contested on the ground of technicalities in the event of jurisdiction. This should not be recognized as a procedural aspect of financing administration for administering the asset by the bank as an amount above the element of cost and profit in the case of a deferred payment asset is construed as usury (riba).

Imposition of maintenance fee as an addition to the selling price was practiced by calling it as administration fee. This is a real danger in legitimizing the illegitimate practice, as it violates the principle of only one price in the contract. In addressing the issue related to the concept of compensation ( $t a^{\prime}$ widh) in practice, it seemed to have been imposed on matured or due financing arising from any failure in making repayment by the customer. This is an area that should be handled properly as the bank has to firstly prove whether there is any element of procrastination. This has to be clearly mentioned in the contract.

In exploring the practices of muqassah / ibra' or rebate, this study noted that there was element of incompleteness in the documentations of the financing. There was lacking in clarity in the documentations for partial redemption. This should be improvised since it was a norm in banking practices to have this kind of dealing as on-going treatments for any long term assets of the bank. This issue needs to be addressed as it relates to matters in dealing with the asset. Furthermore, Islam encourage one to make decision and act wisely, objectively, efficiently, effectively, fair and just and not oppressive unnecessarily.

Further, another point of interest to seller, buyer, tax authority and employer of the buyer party; is the lack of information in the periodical "statement of account (financing under al-BBA)". In fact those parties are the users of such information. This phenomenon should be viewed as the difference in characteristic of the shari'ah-compliant banking product that has to be made as clear as possible. As such, the statement must show element of selling price, cost and profit outstanding. The rule of set-off must be observed appropriately and correctly as to conform to the principle of fairness to mankind.

Another element of gharar or ambiguity that is present in the practices of administration of the asset by the operator was the issue on method of recognition of profit for the respective asset. This was evidence when reconciling the treatment of a lump-sum payment aimed at reducing the progressive released amount. Instead, the result of treatment made has shown that such payment was merely accepted as free money to be utilized in setting of with the periodical progressive profit. The absent of basis in recognizing the income being used, will impair effort to justify the cost of investment on the part of the customer.

Finally, the results of events in dealing with this form of asset of the bank were then recorded detailing all transactions in a statement which supposed to be named statement of Islamic financing account or statement of deferred payment sale account or statement of al-bai' bithaman ajil financing account. On validating the existence of this document, it was sad to say that the mindset of bankers who are so familiar with the conventional approach might have overlooked this for still naming it as a loan account instead of al-BBA financing account. The recording of aggregated amount as a single transaction for a number of transactions in a day in a customer's statement would lead to difficulty in handling the process of reconciliation by the customer. This occurrence should be avoided in future dealings.

\section{Conclusion}

The mission of an Islamic banking institution is to assist in achieving socio-economic justice (al-falah). This study found that, there were a few weaknesses that need to be addressed by the operator. In this paper, the writer outlined that, 
incompetent personnel has given to negative impact on the handling of shari'ah-compliant investment product. This may lead to risk of loosing its niche in term of marketability and confidence in the product, especially from someone who really devoted to dealing with shari'ah-compliant banking operator.

The findings posed in the above discussion are of practical in nature and could easily be understood. Furthermore, they are not difficult to be rectified. The writer hopes that the above findings could be used as evidence for the basis in suggesting an improvement to either the product as well as in addressing the issues related to maintenance to be provided for after the sale to the bank's customer. The writer also suggested that the operator to empirically look into the detail aspects of the product so as to enable it to have a concrete basis in repackaging the product. This is important in ensuring product's sustainability and to remain competitive in business of tense competition.

Dual conflicting functions of shari'ah advisor in setting policies and monitoring the business affairs to ensure its compliance with such policies seemed to pose a danger of violating the related procedures and controls. Pratt (1986) suggested that such lack of independence will diminish its effectiveness due to element of potentially conflicting interest. This situation is further worsened due to the ignorance of the true implication of the very complex procedures and transactions brought before the advisor. The lack of precision in the application of shari'ah principles to Islamic banking activities is also a contributing factor in hindering the success of this sector particularly in the areas of accounting and banking operation. Since this study is limited to a case of a product, the findings might be affected by such constraint in term of the existence or occurrence of the duly analyzed phenomenon.

Based on this study, the writer concluded that the product of shari'ah-compliant banking must be properly packaged in comprehensive manner. This is important, in order to be competitive, effective and efficient to remain sustainable. The pricing must be compatible to any other similar products in the market, the operator must not miss its focus on the target market segment. Placement of its products too, must be properly planned. Above all, the emphasis on product improvement requires immediate action should be taken into consideration on its re-packaging.

The branding of products and services must not be stored in a long list. The branding must not be in too many varieties as this may lead to practicing discriminating selling and be misleading to the customers. Branding of products must be easily read and mention universally. It must be in simple words, which are easy to mention and understand. Its characteristics must also be easily assessed and has competitive niche or specialty edge. Another aspect of packaging that need immediate action for improvement is on the wrapping of product. Currently, the product is not properly wrapped. This has caused inconveniences to the customer in term of effort, time and cost.

Another aspect which the writer considered crucial to be looked into, is the promotion which includes advertising and product-campaign, the operator of Islamic banking business must realize that, they must propagate and promulgate new idea to motivate the customers to be successful in life in this world and the world hereafter. Thus, in this regard, reliance on findings of research would enable the operators in blending activities of marketing and selling as well as providing maintenance services through proper administration of the asset by the bank. As such, there are numerous immediate future research opportunities for potential researcher in this discipline of study that would enable them to contribute in enhancing the reliability and validity of the Islamic banking practices.

\section{References}

BIMB. (1983). Penubuhan dan operasi, Kuala Lumpur. Malaysia. Financial Accounting Organization of Islamic Banking and Financial Institutions. (1994). Objectives and concepts of financial accounting presentation and general disclosure standards and information about organization, Bahrain. (FAOIBFI).

Hj. Mohsin Hj. Mansor. (1984). Undang-undang Perdagangan Dalam Islam, Penerbitan Al-Haramin (M) Sdn Bhd

Islamic Banking Acts. (1983). Jabatan Percetakan Negara. Kuala Lumpur. Malaysia.

Kamel Naser and Maurice Pendlebury,(1997).The influence of Islam on bank financial reporting. International Journal of Commerce and Management.

Kamus Perbankan. (1998). Dewan Bahasa dan Pustaka. Kuala Lumpur. Malaysia.

Karim, R.A.A.. (1995).The nature and rationale of a conceptual framework for financial reporting by Islamic banks. Accounting and business research

Mohd Nasir,M.Y. (2000). The principles and practices of non-interest unit trust funds. Journal of AkauntantsNasional. Kuala Lumpur. Malaysia.

Mohd Nasir, M.Y. (2001). The concept and application of bai bithaman ajil financing in Islamic financial System, Journal of Akauntan Nasional, Kuala Lumpur. Malaysia. April.

Mohd Nasir, M.Y. (2001). Murabahah sale. Journal of Akauntan Nasional. Kuala Lumpur, Malaysia. June.

Mohd Nasir, M.Y. (2004). Investors' perception on the usefulness of corporate annual reports issued by Islamic financial institutions in Malaysia. Proceedings: UNITEN International Conference. December 6-7. Kuantan, Malaysia. 
Mohd Nasir, M.Y. and Noormala, A. (2004). Patronage factors of clients for accounting and management Services businesses in small towns in Malaysia. Proceedings: UNITEN International Conference. December. 6-7.Kuantan, Malaysia.

Mohd Nasir, M.Y. and Amirul Hafiz, M.N. Sept. (2008). Islamic Banking and Finance. Pearson-Prentice Hall. (4 ${ }^{\text {rd }}$ edition) Petaling Jaya, Malaysia. 